\title{
ANALISIS DAMPAK INTEGRASI DATA TERHADAP KECEPATAN PELAYANAN PUBLIK DI KOTA SURABAYA
}

\author{
Renny Sari Dewi \\ Information Systems Department, Universitas Internasional Semen Indonesia, \\ Komplek PT Semen Indonesia (Persero) Tbk, Jl. Veteran Gresik, 61122 Indonesia \\ E-mail: renny.rsd@gmail.com
}

\begin{abstract}
Since 2013, through Surabaya Single Window (SSW), the Government of Surabaya has implemented an innovation in public service (electronic government, e-Government) to integrate citizen's data to the applicant whose domicile is Surabaya. The existence of a synergy between information technology and public services raised a question whether there is any positive impact to the speed of public service provided after the integration of the citizen's data. A survey regarding to response time after filling in an SSW form for technical permissions was conducted to 151 respondents. This research concluded that the factor of data integration through a JSON formatted data-sending service could accelerate the process of population data filling by 80.7 percent or equal to 56.98 seconds faster. In other words, if citizen's data integration is implemented thoroughly, the Public Service Integrated Unit (UPTSA) may be able to receive 2.850 applications files per day.
\end{abstract}

Keywords: e-government, public service, data integration, service speed, SSW

\begin{abstract}
Abstrak
Sejak 2013, melalui Surabaya Single Window (SSW), Pemerintah Kota Surabaya telah melaksanakan inovasi pelayanan publik atau electronic government (e-Government) untuk mengintegrasikan data kependudukan kepada pemohon dengan domisili Kota Surabaya. Adanya sinergi antara teknologi informasi dan pelayanan publik ini menimbulkan pertanyaan terkait dampak positif dari sisi kecepatan pelayanan publik setelah adanya integrasi data kependudukan. Survey mengenai waktu respon saat mengisi permohonan perizinan teknis pada aplikasi SSW telah dilakukan kepada 151 responden. Penelitian ini menyimpulkan bahwa faktor integrasi data melalui sebuah layanan pengiriman data berformat JSON dapat mempercepat proses pengisian data kependudukan sebesar 80.7 persen atau setara dengan lebih cepat 56.98 detik. Ini berarti, apabila integrasi data kependudukan diimplementasikan secara menyeluruh, Unit Pelayanan Terpadu Satu Atap dimungkinkan dapat menerima 2.850 berkas permohonan secara elektronik setiap harinya. (one blank single space line, 10 point font)
\end{abstract}

Kata Kunci: e-government, pelayanan publik, integrasi data, kecepatan pelayanan, SSW

\section{Pendahuluan}

Di era digitalisasi ini, semakin banyak pemerintahan yang gencar menerapkan teknologi informasi, terutama di bidang pelayanan publik. Sistem pemerintahan secara elektronik atau electronic government (e-Government) dinilai sebagai teknologi tepat guna yang mendukung efisiensi dan efektivitas dalam pelayanan publik. Berdasarkan Instruksi Presiden Nomor 3 Tahun 2003 tentang Kebijakan dan Strategi Nasional Pengembangan E-Government, membuat sebagian besar kota/kabupaten di Indonesia yang seolah berlomba-lomba memiliki Rencana Induk Pengembangan (RIP) e-Government. Namun hingga saat ini belum ada daerah yang mengklaim secara ilmiah keberhasilan mengimplementasikan RIP e-Government.
Pemerintah Kota (Pemkot) Surabaya sejak tahun 2013 mengupayakan adanya inovasi di bidang pelayanan publik. Salah satunya adalah meluncurkan aplikasi pelayanan publik berbasis elektronik (electronic government, e-Government) bernama Surabaya Single Window (SSW). Unit Pelayanan Terpadu Satu Atap (UPTSA) dalam hal ini merupakan satuan kerja perangkat daerah yang bertugas untuk mengoperasikan SSW mulai dari menerima berkas permohonan perizinan hingga penyerahan surat izin kepada pemohon [1].

Pengelompokan e-Government idealnya berdasarkan objektif dari pemangku kepentingan dibagi menjadi 4 kategori [2], antara lain pemerintah ke pelaku bisnis (Government-toBusiness, G2B), pemerintah terhadap pemerintah (Government-to-Government, G2G), pemerintah 
terhadap pegawai (Government-to-Employee, G2E), dan pemerintah terhadap penduduk (Government-to-Citizen, G2C). Demikian halnya dengan Pemkot Surabaya hingga memberi klasifikasi khusus pada e-Government berdasarkan Peraturan Walikota Surabaya Nomor 28 Tahun 2013 tentang Tata Cara Pelayanan Perijinan dan Non Perijinan Secara Elektronik di Kota Surabaya [3]. Sedikitnya teridentifikasi ada 60 pelayanan publik dengan rincian 50 perizinan teknis (Tabel 1) dan 10 perizinan non-teknis (lihat Tabel 2) yang saat ini telah tersedia pada SSW [4].

SSW merupakan kios pelayanan publik secara daring yang dapat diakses oleh penduduk dari dalam ataupun luar Kota Surabaya guna berbagai keperluan, di antaranya:

1) Pelayanan perizinan (lihat Tabel 1 dan Tabel 2)

2) Pelayanan kesehatan, contoh: Pendaftaran pasien online di rumah sakit atau puskesmas

3) Pelayanan kependudukan, contoh: Akta kelahiran, akta kematian, surat keterangan pindah

4) Pendaftaran Peserta Didik Baru (PPDB) pada jenjang sekolah dasar hingga menengah atas

5) Pelayanan kecamatan, contoh: KTP elektronik, kartu keluarga

TABEL 1

PERIZINAN DENGAN TEKNIS

\begin{tabular}{|c|c|c|}
\hline & Nama Perizinan Teknis & Kategori \\
\hline 1 & $\begin{array}{l}\text { Surat Keterangan Rencana Kota Untuk } \\
\text { Non Rumah Tinggal, Luas Tanah }< \\
1000 \mathrm{~m} 2\end{array}$ & G2B \\
\hline 2 & $\begin{array}{l}\text { Surat Keterangan Rencana Kota Sudah } \\
\text { Ada Perencanaan (SAP) Untuk Rumah } \\
\text { Tinggal, Luas Tanah }>200 \mathrm{~m} 2\end{array}$ & $\mathrm{G} 2 \mathrm{C}$ \\
\hline 3 & $\begin{array}{l}\text { Surat Keterangan Rencana Kota Untuk } \\
\text { Non Rumah Tinggal, Luas Tanah }< \\
1000 \mathrm{~m} 2\end{array}$ & G2B \\
\hline 4 & $\begin{array}{l}\text { Surat Keterangan Rencana Kota Belum } \\
\text { Ada Perencanaan (BAP) Dan Non } \\
\text { Rumah Tinggal, Luas Tanah }>1000 \mathrm{~m} 2\end{array}$ & G2B \\
\hline 5 & $\begin{array}{l}\text { Site Plan, Replanning, Perubahan } \\
\text { Peruntukan }\end{array}$ & G2B \\
\hline 6 & $\begin{array}{l}\text { IMB Rumah Tinggal }<2 \text { Lantai, Luas } \\
\text { Tanah }<200 \mathrm{~m} 2\end{array}$ & $\mathrm{G} 2 \mathrm{C}$ \\
\hline 7 & $\begin{array}{l}\text { IMB Non Rumah Tinggal (melalui } \\
\text { proses bintek terlebih dahulu) }\end{array}$ & G2B \\
\hline 8 & $\begin{array}{l}\text { IRB Rumah Tinggal Dan Non Rumah } \\
\text { Tinggal }\end{array}$ & $\begin{array}{l}\mathrm{G} 2 \mathrm{~B}, \\
\mathrm{G} 2 \mathrm{C}\end{array}$ \\
\hline 9 & Ijin Mendirikan Rumah Ibadah & G2B \\
\hline & Ijin Gangguan (HO) (Permohonan Baru) & G2B \\
\hline 11 & Ijin Gangguan (HO) (Daftar Ulang) & G2B \\
\hline 12 & Ijin Gangguan (HO) (Pengalihan Hak) & G2B \\
\hline & $\begin{array}{l}\text { Ijin Atas Pemakaian Tanah Sempadan } \\
\text { Baru/Baliknama/Pelimpahan/Per- } \\
\text { panjangan }\end{array}$ & $\begin{array}{l}\mathrm{G} 2 \mathrm{~B}, \\
\mathrm{G} 2 \mathrm{C}\end{array}$ \\
\hline 14 & Peresmian Ijin Sewa Tanah & G2B \\
\hline & Pemutihan Ijin Sewa Tanah & $\begin{array}{l}\mathrm{G} 2 \mathrm{~B}, \\
\mathrm{G} 2 \mathrm{C}\end{array}$ \\
\hline & Perpanjangan Ijin Pemakaian Tanah & $\begin{array}{l}\text { G2B, } \\
\text { G2C }\end{array}$ \\
\hline 17 & Pengalihan Hak/Balik Nama Ijin & $\mathrm{G} 2 \mathrm{~B}$ \\
\hline
\end{tabular}

\section{No Nama Perizinan Teknis \\ Pemakaian Tanah}

18 Ijin Perusahaan Pengambilan Air Bawah Tanah

19 Ijin Usaha Perusahaan Pengeboran Air Bawah Tanah

20 Ijin Perpanjangan Perusahaan Pengeboran Air Bawah Tanah

21 Ijin Pengeboran Air Bawah Tanah

22 Ijin Pengambilan Air Bawah Tanah (Untuk Sumur Bor)

23 Ijin Pengambilan Air Bawah Tanah (Untuk Sumur Gali)

24 Ijin Perpanjangan Pengambilan Air Bawah Tanah untuk Sumur Gali

25 Ijin Explorasi Air Bawah Tanah

26 Ijin Perpanjangan Eksplorasi Air Bawah Tanah

27 Ijin Pembuangan Air Limbah

28 Ijin Penyelenggaraan Pameran Skala Lokal

29 Ijin Penyelenggaraan Pameran Skala Regional

30 Ijin Penyelenggaraan Pameran Skala Nasional \& Internasional

31 Ijin Penyelenggaraan Tempat Parkir

32 Surat Ijin Usaha Perdagangan (SIUP)

33 Ijin Usaha Jasa Pelaksanaan Pekerjaan Konstruksi

34 Ijin Usaha Jasa Konsultasi Perencanaan \& Pengawasan Pekerjaan Konsultasi

35 Ijin Instalasi Listrik

36 Ijin Instalasi Penyalur Petir

37 Ijin Pengangkutan Jenazah/ Kerangka

38 Ijin Perabuan Jenazah/Kerangka

39 Ijin Pemindahan Jenazah/Kerangka

40 Tanda Daftar Industri (TDI)

41 Tanda Daftar Gudang (TDG) (> 100 $\mathrm{m} 2$ )

42 Ijin Pembuangan Limbah Cair

43 Ijin Usaha Showbiz (Pertujukan Umum)

44 Ijin Usaha Bersyarat

45 Pelayanan Pendaftaran Bangunan dan/atau Lingkungan Cagar Budaya

46 Pelayanan Ijin Pemanfaatan Bangunan dan/atau Cagar Budaya

47 Pelayanan Ijin Pemugaran Bangunan G2B dan/atau Cagar Budaya

48 Ijin Penyelenggaraan Reklame

49 Ijin Mendirikan Bangunan Menara diatas Bangunan (roof top)

50 Ijin Mendirikan Bangunan Menara diatas Permukaan tanah (Green Field)

Kategori

G2B

G2B

G2B,

G2C

G2B,

$\mathrm{G} 2 \mathrm{C}$

G2B,

G2C

G2B

G2B

G2B

G2B

G2B

G2B

G2B

G2B

G2B

G2B

G2B

G2B,

G2C

G2B,

$\mathrm{G} 2 \mathrm{C}$

G2B,

$\mathrm{G} 2 \mathrm{C}$

G2B,

G2C

G2B

G2B

G2B

G2B

G2B

G2B

G2B

G2B

G2B

G2B

Sumber: Data diolah, 2016 [4] [5]

TABEL 2

PERIZINAN NON-TEKNIS

\begin{tabular}{cll}
\hline No & Nama Perizinan Non-Teknis & Kategori \\
\hline 1 & $\begin{array}{l}\text { Surat Keterangan Pencari Kerja } \\
\text { (Kartu Kuning) }\end{array}$ & G2C \\
2 & Surat Tanda Pendaftaran (STP) Orsos, & G2B \\
& Yayasan, LSK-UKS & \\
3 & Rekomendasi Pengalihan Hak & G2B \\
4 & Rekomendasi Bank & G2B \\
5 & Rekomendasi IMB & G2B, G2C \\
6 & Rekomendasi Bantuan Organisasi & G2B
\end{tabular}




\author{
Sosial \\ 7 Rekomendasi Bantuan Tempat Ibadah G2B \\ 8 Rekomendasi Undian Gratis G2B \\ Berhadiah (RUGB) \\ 9 Pemberitahuan Keberadaan Ormas, G2B \\ LSM dan Yayasan \\ 10 Surat Keterangan Terdaftar (SKT) G2B \\ Orkemas
}

Sumber: Data diolah, 2016 [4] [5]

Menurut Jawa Pos [6], UPTSA kini mampu menangani 261 perizinan. Dari sumber tersebut dijelaskan pula bahwa UPTSA telah menambah loket baru yang awalnya 14 menjadi 30 unit. Hal ini guna mengantisipasi membeludaknya pemohon yang rata-rata per harinya mencapai 500 orang akibat sentralisasi perizinan yang dilakukan Pemkot Surabaya [7].

Dari uraian di atas, peneliti tertarik untuk melakukan riset analisis dampak integrasi data kependudukan terhadap waktu respon pada aplikasi perizinan di SSW. Berdasarkan pernyataan seorang informan dari Dinas Kependudukan dan Pencatatan Sipil, pihaknya telah memberikan akses legal kepada sejumlah Satuan Kerja Perangkat Daerah (SKPD) di lingkungan Pemkot Surabaya untuk menggunakan layanan data kependudukan guna mempercepat pengisian data diri pemohon saat membuat permohonan perizinan.

Penelitian DeLone \& McLean [8] tentang sebuah model evaluasi adopsi model kesuksesan sistem informasi yang tersusun atas beberapa faktor yang dapat mempengaruhi kinerja individu maupun organisasi apabila telah menerapkan suatu teknologi informasi. Salah satu faktornya adalah kualitas sistem. Kualitas sistem terdiri dari beberapa indikator [9], di antaranya kemampuan beradaptasi, ketersediaan, kehandalan, integrasi integrasi data diinterpretasikan dengan waktu respon terhadap jumlah penggunaan, frekuensi penggunaan, dan tingkat penggunaan yang berasal dari berbagai departemen atau divisi yang saling terkait untuk berbagi data [10].

\section{Penelitian Terkait}

Dalam kurun waktu tiga dekade terakhir, tepatnya tahun 1989 sudah mulai dikenal metode untuk mengukur kesuksesan adopsi teknologi informasi. Beberapa metode di antaranya yang cukup sering digunakan adalah: Technology Acceptance Model (TAM) [11], Diffusion of Innovations (DOI) [12], Unified Theory of Acceptance and Use of Technology (UTAUT) [12], dan Information System Success Model (ISSM) yang digagas oleh DeLone \& McLean atau yang juga dikenal sebagai Model Kesuksesan Sistem Informasi (MKSI) tahap pertama [4] dan kedua [13]. Masing-masing metode evaluasi tentu memiliki karakteristik atau keunggulan dibandingkan dengan metode lainnya.

Peneliti merangkum skema riset analisis dampak integrasi data terhadap kecepatan pelayanan publik pada SSW seperti yang tersaji pada Gambar 1. Integrasi data merupakan salah satu faktor penting dalam menentukan kualitas sistem sekaligus fokus utama yang akan dilakukan investigasi.

Dalam hal ini, peneliti berfokus pada faktor integrasi khususnya dalam penggunaan data. Namun dari beberapa metode evaluasi $e$ Government yang sudah ada, belum pernah membahas lebih detil mengenai teknis pengujian pengaruh integrasi data pada kualitas sistem $e$ Government terhadap kecepatan pelayanan (salah satu faktor penentu kualitas layanan dan kepuasan pengguna). Penelitian terdahulu tentang evaluasi adopsi e-Government tersaji dalam Tabel 3.

data, dan kemudahan penggunaan. Indikator

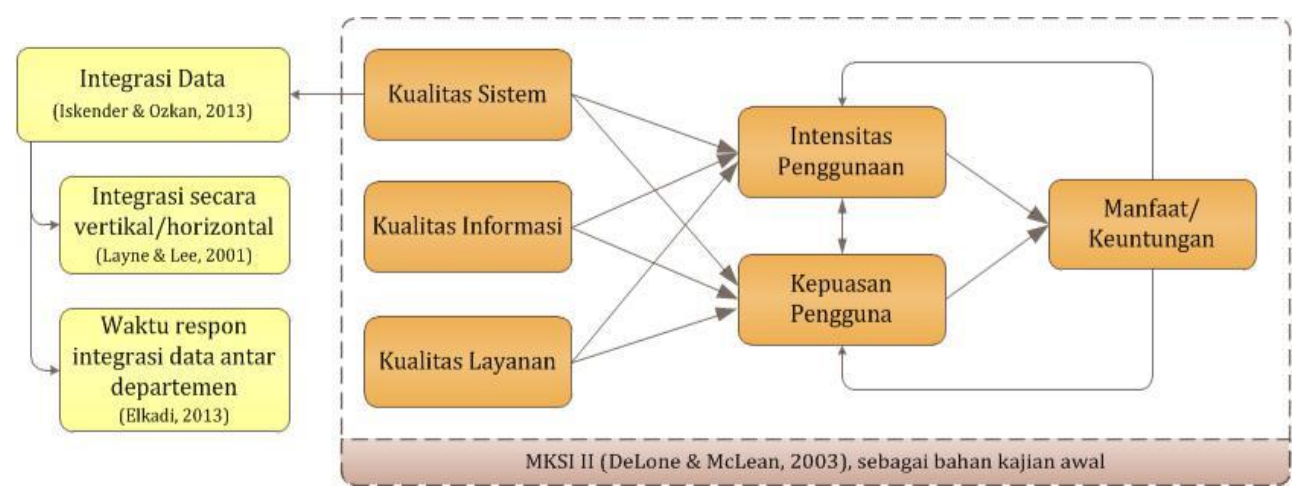

Gambar. 1. Skema Penelitian Berdasarkan Kajian Pustaka 


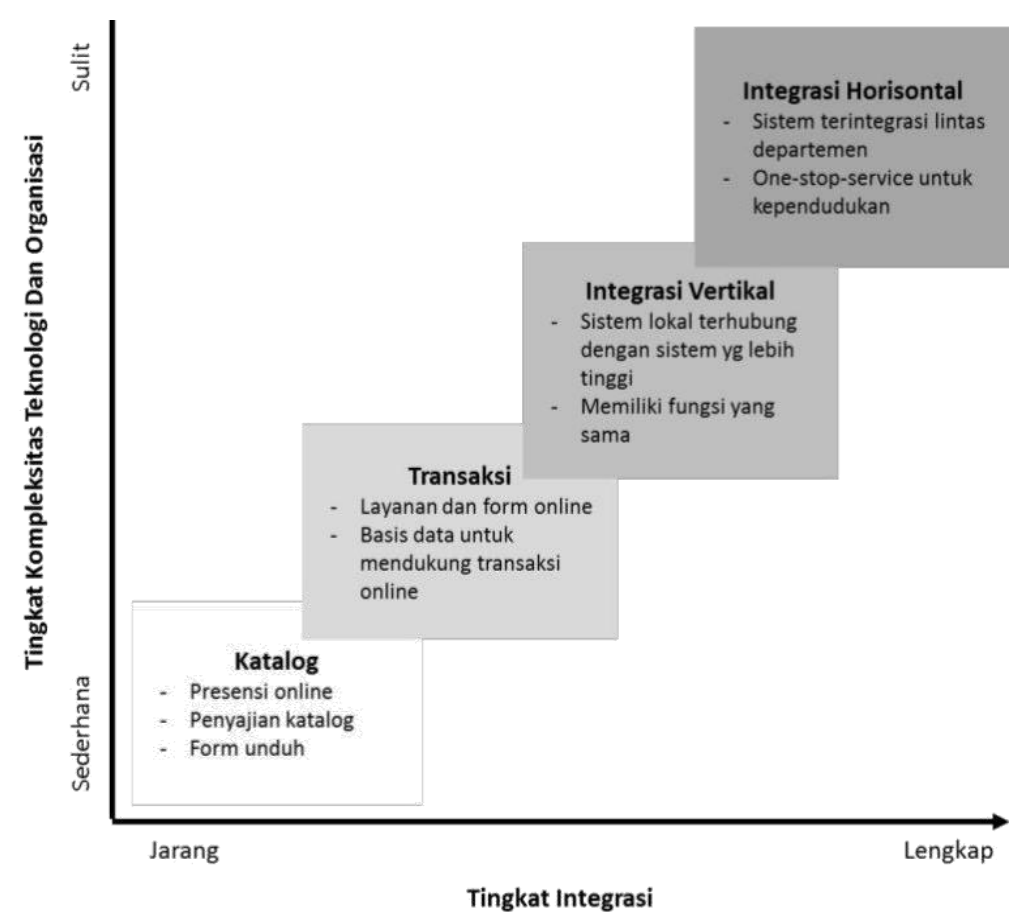

Gambar. 2. Dimensi dan Tahapan Pengembangan E-Government [14]

TABEL 3

Penelitian Sebelumnya tentang Metode Evaluasi E-GovernMent

\begin{tabular}{|c|c|c|c|}
\hline $\begin{array}{l}\text { Nama Peneliti, } \\
\text { Tahun }\end{array}$ & $\begin{array}{l}\text { Metode Evaluasi yang } \\
\text { Digunakan }\end{array}$ & Kaitan dengan Penelitian Ini & Celah Penelitian \\
\hline $\begin{array}{l}\text { DeLone \& McLean, } \\
1992[4] \\
\text { DeLone \& McLean, } \\
2003 \text { [8] }\end{array}$ & $\begin{array}{l}\text { MKSI I } \\
\text { MKSI II (perbedaan } \\
\text { dengan MKSI I yaitu } \\
\text { penambahan aspek } \\
\text { Kualitas layanan) }\end{array}$ & $\begin{array}{l}\text { Sebagai bahan kajian awal untuk } \\
\text { menganalisis kuantitatif untuk } \\
\text { mengetahui korelasi antar } \\
\text { variabel. }\end{array}$ & $\begin{array}{l}\text { Faktor integrasi hanya berfokus pada } \\
\text { integrasi efisiensi dan efektivitas } \\
\text { waktu yang berdampak pada } \\
\text { Kecepatan pelayanan. }\end{array}$ \\
\hline $\begin{array}{l}\text { Layne \& Lee, } 2001 \\
{[15]}\end{array}$ & E-Government Stages & $\begin{array}{l}\text { Sebagai bahan kajian utama } \\
\text { untuk melakukan analisis dampak } \\
\text { apakah integrasi data bersifat } \\
\text { vertikal atau horisontal }\end{array}$ & - \\
\hline $\begin{array}{l}\text { Iskender \& Ozkan, } \\
2013 \text { [10] }\end{array}$ & MKSI II & $\begin{array}{l}\text { Sebagai landasan ide untuk } \\
\text { melakukan analisis secara teknis } \\
\text { pada tingkatan integrasi }\end{array}$ & $\begin{array}{l}\text { Tidak disertakan komponen yang } \\
\text { mempengaruhi faktor integrasi pada } \\
\text { level teknis }\end{array}$ \\
\hline Elkadi, 2013 [9] & MKSI II & $\begin{array}{l}\text { Sebagai bahan kajian untuk } \\
\text { pengujian kualitas sistem melalui } \\
\text { integrasi data antar departemen } \\
\text { pada } e \text {-Government Mesir }\end{array}$ & $\begin{array}{l}\text { Belum diuji integrasi data apa saja } \\
\text { yang diterapkan dan yang } \\
\text { diintegrasikan pada e-Government } \\
\text { Mesir }\end{array}$ \\
\hline $\begin{array}{l}\text { Dewi \& Mudjahidin, } \\
2013 \text { [16] }\end{array}$ & $\begin{array}{l}\text { Government Adoption } \\
\text { Model (GAM) }\end{array}$ & $\begin{array}{l}\text { Pernah diterapkan di } e \text { - } \\
\text { Government Kota Surabaya yaitu } \\
\text { SSW }\end{array}$ & $\begin{array}{l}\text { Belum memperlihatkan pentingnya } \\
\text { faktor integrasi data antar satuan kerja } \\
\text { perangkat daerah }\end{array}$ \\
\hline
\end{tabular}

Pada Gambar 2, integrasi data terbagi menjadi 4 tingkatan. Tingkatan katalog dan transaksi menurut Layne, et al. [15] merupakan kategori e-Government yang telah diterapkan pada umumnya yaitu kategori G2G dan G2E [2].

Adanya korelasi antara tingkat integrasi terhadap kompleksitas teknologi dan organisasi, menjadikan matriks pengelompokan tingkatan memiliki makna tertentu. Pada studi kasus yang diteliti, maka aplikasi pelayanan publik berbasis G2B dan G2C dikategorikan pada integrasi data secara vertikal. Artinya, integrasi data dalam konteks aplikasi pelayanan publik, telah merujuk pada tingkatan ketiga, yaitu tingkat integrasi sedang dan kompleksitas yang cukup sulit (perhatikan Gambar 2).

\section{Metodologi}

Pendekatan yang digunakan oleh peneliti bersifat kualitatif. Tahapan-tahapan yang dilakukan oleh peneliti adalah seperti yang tersaji pada Gambar 3 . 


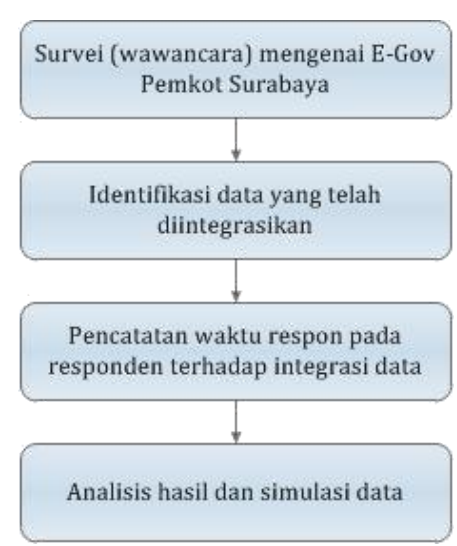

Gambar. 3. Tahapan Penelitian

\section{Pengumpulan Data Tentang e-Government Pemerintah Kota Surabaya}

Wawancara sekaligus justifikasi dilakukan peneliti kepada Bidang e-Government Dinas Komunikasi dan Informatika (Diskominfo) mengenai aplikasi layanan publik SSW yang telah diintegrasikan dengan Dinas Kependudukan dan Pencatatan Sipil (Dispendukcapil). Dari hasil wawacanra tersebut, diperoleh data perizinan teknis dengan frekuensi pengajuan secara periodik. Peneliti kemudian melakukan pemilahan sebanyak 2 (dua) perizinan teknis yang memiliki frekuensi pengajuan permohonan paling tinggi.

\section{Identifikasi Data yang Telah Terintegrasi}

Tahap berikutnya adalah peneliti melakukan identifikasi data yang telah dilakukan integrasi. Sejak 2014, data yang berhasil diintegrasikan adalah data kependudukan yang aksesnya diberikan oleh Dispendukcapil. Data kependudukan yang berasal dari Sistem Informasi Administrasi Kependudukan (SIAK) yang kemudian disajikan dalam format JSON. Tabel 4 merupakan rincian data kependudukan berdasarkan Kartu Tanda Penduduk elektronik (KTP-el).

Menurut informasi yang didapatkan dari Diskominfo, pada 2014 layanan integrasi data pada aplikasi SSW terbatas pada penduduk yang berdomisili di Kota Surabaya. Hal ini ditunjukkan dengan NIK dengan 4 digit awal adalah 3578xxx. Maka dari itu, peneliti melakukan observasi kepada 2 jenis responden, yaitu penduduk dalam kota dan luar Kota Surabaya. Penduduk dalam Kota Surabaya untuk mengetahui waktu respon terhadap integrasi data. Sedangkan, penduduk luar Kota Surabaya untuk mengetahui waktu respon yang tidak dapat dijangkau layanan integrasi data.

TABEL 4

RINCIAN DATA KEPENDUDUKAN BERDASARKAN KTP-EL

\begin{tabular}{clll}
\hline ID & Data yang Diintegrasikan & Detil Atribut Data & Tipe \\
\hline 1 & Nomor Induk Kependudukan (NIK) & Terdiri dari 16 digit angka & Wajib isi \\
2 & Nama & Terdiri dari kombinasi huruf dan simbol & Wajib isi \\
3 & Alamat & Terdiri dari kombinasi huruf, angka, dan simbol & Wajib isi \\
4 & Kelurahan & Terdiri dari huruf & Pilihan \\
5 & Kecamatan & Terdiri dari huruf & Pilihan \\
6 & Tempat Lahir & Terdiri dari huruf & Pilihan \\
7 & Tanggal Lahir & Terdiri dari angka hari-bulan-tahun & Pilihan (format hh-bb-tttt) \\
8 & Status Kawin & Terdiri dari huruf & Pilihan \\
9 & Pekerjaan & Terdiri dari huruf & Pilihan \\
10 & Golongan Darah & Terdiri dari kombinasi huruf dan simbol & Opsi \\
\cline { 2 - 4 }
\end{tabular}

\section{Pencatatan Waktu Respon Tiap Responden}

Kepada sejumlah responden yang merupakan pemohon dari 2 teratas perizinan teknis yang sering diajukan, peneliti melakukan pengujian data. Pengujian data yang dimaksud adalah peneliti mencatat waktu respon apabila pemohon hendak mengisikan data diri (lihat Tabel 4) dengan menggunakan stopwatch pada telepon genggam. Dari hasil pencatatan waktu, peneliti mendapatkan waktu respon beserta deviasinya untuk dapat dianalisis dan disimulasikan.

\section{Analisis Hasil dan Simulasi Data}

Jika waktu respon pada data pemohon yang juga merupakan data kependudukan telah tercatat dengan baik, maka selanjutnya peneliti melakukan simulasi data berdasarkan deviasi/selisih waktu respon. Simulasi yang dilakukan peneliti bertujuan untuk mengetahui apakah integrasi data sudah optimal terhadap sumber daya yang dimiliki UPTSA saat ini. 


\section{Hasil dan Pembahasan}

\section{Analisis Hasil Survey}

Sejumlah 151 responden yang mengajukan permohonan perizinan teknis di UPTSA, terdiri dari 134 pemohon dari Kota Surabaya dan 17 pemohon dari luar Kota Surabaya. Terdapat dua perizinan terbanyak diajukan kepada UPTSA yaitu Surat Izin Usaha Perdagangan (SIUP) dan Ijin Gangguan (HO) untuk permohonan baru. Data selengkapnya dapat dilihat pada Tabel 5.

TABEL 5

Distribusi Pemohon Perizinan TeKNis SSW

\begin{tabular}{clc}
\hline No & Nama Perizinan Teknis & Responden \\
\hline 1 & IMB Rumah Tinggal <2 Lantai, Luas & 3 \\
& Tanah < 200 m 2 $^{2}$ & \\
2 & IMB Non Rumah Tinggal (melalui & 1 \\
& proses bintek terlebih dahulu) & 2 \\
3 & Ijin Mendirikan Rumah Ibadah & 23 \\
4 & Ijin Gangguan (HO) (Permohonan Baru) & 11 \\
5 & Ijin Gangguan (HO) (Daftar Ulang) & \\
6 & Ijin Penyelenggaraan Pameran Skala & 5 \\
& Lokal & 7 \\
7 & Ijin Penyelenggaraan Tempat Parkir & 62 \\
8 & Surat Ijin Usaha Perdagangan (SIUP) & \\
9 & Ijin Usaha Jasa Pelaksanaan Pekerjaan & 4 \\
& Konstruksi & 3 \\
10 & Ijin Instalasi Penyalur Petir & 6 \\
11 & Ijin Pengangkutan Jenazah/ Kerangka & 15 \\
12 & Tanda Daftar Industri (TDI) & 1 \\
13 & Tanda Daftar Gudang (TDG) (>100 m ${ }^{2}$ ) & 1 \\
\hline & $\quad$ Total Responden & 151
\end{tabular}

Berdasarkan pengamatan di lapangan, penduduk luar Kota Surabaya yang mengajukan permohonan perizinan teknis diharuskan mengisi data diri lengkap satu per satu sesuai isian yang ditentukan aplikasi. Peneliti melakukan pencatatan terhadap rata-rata waktu respon yang dilakukan oleh setiap responden luar Kota Surabaya. Tabel 6 menunjukkan bahwa total rata-rata dan deviasi pengisian data kependudukan responden dari luar Kota Surabaya sebesar 70.63 detik.
TABEL 6

Hasil PENCATATAN WAKTu RESPon Pada PEMOHON LUAR KoTA SURABAYA

\begin{tabular}{|c|c|c|}
\hline ID & Data yang Diintegrasikan & Rata-rata (detik) \\
\hline 1 & NIK & 12,23 \\
\hline 2 & Nama & 13,08 \\
\hline 3 & Alamat & 16,05 \\
\hline 4 & Kecamatan & 2,83 \\
\hline 5 & Kelurahan & 2,28 \\
\hline 6 & Tempat Lahir & 6,53 \\
\hline 7 & Tanggal Lahir & 11,20 \\
\hline 8 & Status Kawin & 1,50 \\
\hline 9 & Pekerjaan & 2,45 \\
\hline 10 & Golongan Darah & 2,50 \\
\hline
\end{tabular}

Sebaliknya, pengamatan yang dilakukan kepada responden yang merupakan pemohon dari Kota Surabaya membutuhkan waktu respon ratarata sekitar 13.65 detik. Hal ini disebabkan oleh isian yang diharuskan hanya berupa NIK. Oleh sebab itu, kesenjangan waktu respon antara pemohon dari dalam maupun luar Kota Surabaya dikomparasikan agar memperoleh deviasi waktu respon (lihat Tabel 7).

Tabel 7 menunjukkan bahwa adanya perbedaan yang sangat signifikan antara kecepatan pengisian data antara sebelum dan sesudah integrasi data NIK. Dari hasil pencatatan waktu keseluruhan responden yang diobservasi, rata-rata deviasi waktu pengisian data kependudukan mencapai 56.98 detik. Oleh karenanya, peneliti berasumsi bahwa setelah diberlakukannya integrasi data NIK mampu mempercepat proses pengisian data kependudukan sebesar $80.7 \%$.

\section{Simulasi Optimalisasi Permohonan Perizinan}

Pada uraian di atas telah disampaikan kondisi kekinian di UPTSA dalam menangani pelayanan perizinan, baik pemohon dari dalam maupun luar Kota Surabaya. Adanya integrasi data memiliki dampak bagi pelayanan publik akan dilihatkan pada Tabel 7.

TABEL 7

PERBANDINGAN WAKTU RESPON RATA-RATA RESPONDEN (DALAM DETIK)

\begin{tabular}{rlrrr}
\hline ID & Data yang Diintegrasikan & $\begin{array}{c}\text { Responden Dalam } \\
\text { Kota Surabaya }\end{array}$ & $\begin{array}{c}\text { Responden Luar } \\
\text { Kota Surabaya }\end{array}$ & Deviasi \\
\hline 1 & NIK & 12,23 & & 13,65 \\
2 & Nama & 13,08 & 0 & $-1,42$ \\
3 & Alamat & 16,05 & 0 & 13,08 \\
4 & Kecamatan & 2,83 & 0 & 2,83 \\
5 & Kelurahan & 2,28 & 0 & 2,28 \\
6 & Tempat Lahir & 6,53 & 0 & 6,53 \\
7 & Tanggal Lahir & 11,20 & 0 & 11,20 \\
8 & Status Kawin & 1,50 & 0 & 1,50 \\
9 & Pekerjaan & 2,45 & 0 & 2,45 \\
10 & Golongan Darah & 2,50 & 0 & 2,50 \\
\hline
\end{tabular}


96 Jurnal Sistem Informasi (Journal of Information System), Volume 14, Issue 2, October 2018

\begin{tabular}{|c|c|c|}
\hline Total (detik) & 70,63 & 56,98 \\
\hline Deviasi & $19,3 \%$ & $80,7 \%$ \\
\hline \multicolumn{3}{|c|}{$\begin{array}{l}\text { TABEL } 8 \\
\text { DATA UNTUK PEMOHON LUAR KOTA SURABAYA }\end{array}$} \\
\hline Kondisi Saat Ini & \multicolumn{2}{|l|}{ Simulasi } \\
\hline 1 pemohon membutuhkan waktu 70.63 detik (A) & \multicolumn{2}{|l|}{1 pemohon membutuhkan waktu 13,65 detik } \\
\hline $\begin{array}{l}1 \text { hari dapat melayani } \mathbf{5 0 0} \text { pemohon }(\mathrm{B}) \\
\text { Total loket } 30 \text { buah }(\mathrm{C})\end{array}$ & \multicolumn{2}{|c|}{$\begin{array}{l}\text { Dengan TW yang diperlukan selama } 1 \text { hari tiap loket } 1.177,17 \\
\text { detik, maka: }\end{array}$} \\
\hline $\begin{array}{l}\text { Total waktu (TW) yang diperlukan dalam } 1 \text { hari } \\
\text { tiap loket: }\end{array}$ & \multicolumn{2}{|c|}{$\begin{array}{l}\text { Jumlah pemohon dalam } 1 \text { hari = waktu per loket dibagi waktu } \\
\text { per pemohon }\end{array}$} \\
\hline$T W=\frac{A * B}{C} \approx T W=\frac{500 * 70,63}{30}=1.177,17$ detik & \multicolumn{2}{|c|}{$\Sigma$ Pemohon $=\frac{1.177,17}{13,65} * 30$ loket $=\mathbf{2 . 5 8 0}$ pemohon dalam 1 ha } \\
\hline
\end{tabular}

Dari Tabel 8 di atas, dapat disimpulkan apabila integrasi data dapat diimplementasikan secara menyeluruh tanpa memandang data pemohon apakah berasal dari Kota Surabaya maupun luar Kota Surabaya, dapat dioptimalkan kecepatan pelayanan UPTSA sehingga mampu melayani 2.580 pemohon per harinya, atau meningkat 5 kali lipat dari kondisi awal yang 'hanya' 500 pemohon.

\section{Kesimpulan}

Berdasarkan uraian hasil dan pembahasan, maka dapat disimpulkan beberapa poin berikut:

1. Penelitian dilakukan pada aplikasi pelayanan publik Surabaya Single Window untuk kategori G2B dan G2C.

2. Integrasi data yang telah berhasil dilakukan berdasarkan informasi dari Dinas Kependudukan dan Pencatatan Sipil adalah data kependudukan yang terdiri dari: Nomor Induk Kependudukan (NIK), Nama, Alamat,

\section{Referensi}

[1] UPTSA, "Unit Pelayanan Terpadu Satu Atap,"

[2] Pemerintah Kota Surabaya, 2016. [Online]. Available:

http://uptsa.surabaya.go.id/detil.php?p=tup. [Diakses 6 November 2016].

[3] V. Rao, "Collaborative Government to Employee (G2E):

[4] Issues and Challenges to E-Government," Journal of E-Government, vol. 34, no. 4, pp. 214-229, 2011.

[5] UPTSA, "Unit Pelayanan Terpadu Satu Atap,"

[6] Pemerintah Kota Surabaya, 2011. [Online]. Available:
Kecamatan, Kelurahan, Tempat Lahir, Tanggal Lahir, Status Kawin, Pekerjaan, dan Golongan Darah. Dinas Kependudukan dan Pencatatan Sipil membukakan akses terhadap 10 data kependudukan kepada satuan kerja perangkat daerah agar dapat mempercepat proses pelayanan publik.

3. Observasi dilakukan kepada 151 responden yang terbagi menjadi dua yaitu 134 pemohon dari Kota Surabaya dan 17 pemohon dari luar Kota Surabaya yang sedang mengajukan permohonan perizinan teknis.

4. Teknologi integrasi data menggunakan layanan pengiriman data berformat JSON dapat mempercepat pemohon saat pengisian data kependudukan dengan rata-rata deviasi 80.7 persen atau setara dengan 56.98 detik. Karenanya, apabila seluruh data kependudukan diintegrasikan, diprediksi dalam satu hari UPTSA dapat melayani 2.580 permohonan.

http://uptsa.surabaya.go.id/detil.php?p=perp. [Diakses 1 Mei 2017].

[7] SSW, "Kios Pelayanan Publik," Pemerintah Kota

[8] Surabaya, 2015. [Online]. Available: http://ssw.surabaya.go.id/anjungan/. [Accessed 1 Mei 2017].

[9] UPTSA, "Unit Pelayanan Terpadu Satu Atap," Pemerintah Kota Surabaya, 2011. [Online]. Available: http://uptsa.surabaya.go.id/detil.php?p=lay. [Accessed 1 Mei 2017].

[10] JawaPos, "Press Reader," PT Jawa Pos, 31 Januari 2017.

[11] [Online]. Available: https://www.pressreader.com/indonesia/jawa -pos/20170131/282364039402552. [Diakses 2 Mei 2017]. 
[12] Transformasi, "Transformasi: Center for Public Policy Transformation," Transformasi, 9 Februari 2016.

[13] [Online]. Available: http:/www.transformasi.org/id/pusatkajian/berita/penciptaan-lapangankerja/1490-perizinan-surabaya-pemkotterapkan-proses-terintegrasi. [Diakses $5 \mathrm{Mei}$ 2017].

[14] W. DeLone dan E. McLean, "The DeLone and McLean model of information systems success: A ten year update," Journal of Management Information Systems, vol. 19, no. 4, pp. 9-30, 2003.

[15] H. Elkadi, "Success and failure factors for egovernment projects: A case from Egypt," Egyptian Informatics Journal, vol. 14, no. 2, pp. 165-173, 2013.

[16] G. Iskender and S. Ozkan, "E-government transformation success: An assessment methodology and the preliminary results," Transforming Government: People, Process and Policy, vol. 7, no. 3, pp. 364-392, 2013.

[17] F. Davis, "Perceived Usefulness, Perceived Ease of Use, and User Acceptance of IT," MIS Quarterly, vol. 13, pp. 983-1003, 1989.

[18] E. Rogers, Diffusion of Innovations, New York: Free Press, 1995.
[19] V. Venkatesh, M. Morris, G. Davis dan F. Davis, "User Acceptance of IT: Toward a Unified View," MIS Quarterly, vol. 27, no. 3, pp. 425-478, 2003

[20] W. DeLone dan E. McLean, "Information systems success: The quest for the dependent variable,"

[21] Information System Research, vol. 3, no. 1, pp. 60-95, 1992.

[22] K. Layne and J. Lee, "Developing fully functional e-government: A four stage model," Government information quarterly, vol. 18, no. 2, pp. 122-136, 2001.

[23] L. A. S. Dewi and Mudjahidin, "ANALISIS PENERAPAN APLIKASI SURABAYA SINGLE WINDOWS PEMERINTAH KOTA SURABAYA MENGGUNAKAN GOVERNMENT ADOPTION MODEL (GAM)," Jurnal Teknik Pomits, vol. 2, no. 1, 2013.

[23] Surya, "Surya Tribunnews," 2016. [Online]. Available:

http://surabaya.tribunnews.com/2016/09/28/ pemerintah-daerah-se-indonesia-adopsisistem-e-government-pemkot-surabaya. [Diakses 6 November 2016]. 